\title{
Influence of various obturation techniques and materials on postoperative pain - A Systematic review
}

\author{
Kousalya Vuyyuru ${ }^{1}$, Nivedhitha Malli Sureshbabu ${ }^{2}$ \\ ${ }^{1,2}$ (Department Of Conservative Dentistry And Endodontics, Saveetha Dental College, India)
}

\begin{abstract}
Background: Pain is an unwanted yet unfortunately common sensation after root canal treatment which commences a few hours or days after treatment and is always an unpleasant experience for both patients and clinicians. The reasons for postoperative pain can be many including chemical, mechanical or microbial injuries to the periapical tissues that result in acute inflammation

Search strategy: The following databases were searched: PubMed CENTRAL (until July 2015), and Cochrane Database of Systematic Reviews. Bibliographies of clinical studies and reviews identified in the electronic search were analyzed for studies published outside the electronically searched journals.

Main results : The result of this systematic review showed that obturation technique and material were not found to be significantly associated with postoperative pain.

Conclusion : There was no conclusion evidence on the influence of obturation technique and materials on post treatment pain. Hence, more properly designed high quality randomized clinical trials are needed to evaluate the effect of obturation technique and materials in post - treatment pain.
\end{abstract}

Keywords: Root filling techniques, Obturation materials, Post treatment pain, Root canal therapy

\section{Introduction}

Root canal treatment or endodontic therapy is performed to manage pain and eliminate infection from teeth. After root canal treatment, postoperative pain has been reported from 1.9\% - 48\% (6,7). Post obturation pain severity demonstrated a steady decrease in postoperative pain prevalence over time (9). It may persist from few hours to many days after root canal treatment (7). The factors responsible for postoperative pain are unclear.

Mechanical factors including overinstrumentation or extrusion of obturation materials, have been associated with the presence of postoperative pain (8).

Postoperative pain is common after root canal treatment, so it is very important for the dentist to control this pain as well as to know how widespread the problem is (10). The development of post-treatment pain of mild intensity is not a rare event, even when endodontic treatment has followed acceptable standards. The occurrence of inter-appointment discomforts is approximately 50\% of 2000 patients who underwent endodontic therapy in pulp less teeth (13). In addition, the Hawthorne effect; the change in the behavior of a subject because of the special attention and status received from participation in an investigation (12), can provoke the patients to overestimate their pain levels.

Root canal treatment must be carried out taking into consideration that instrumentation and obturation techniques can provoke periapical damage. Furthermore, several reports reported that extrusion of filling material is associated with presence of postoperative pain $(6,7)$. The objective of this systematic review was to evaluate the influence of various obturation methods and obturation materials on postoperative pain.

\subsection{Aim}

The aim of this systematic review was to evaluate the influence of various obturation methods and obturation materials on postoperative pain.

1.2. Structured Question

Is there a difference in postoperative pain between various obturation techniques and materials?

\section{Materials and Methods}

Sources Used for identification of studies included or considered for this review, detailed search strategies were carried out on the following databases.

\subsection{Searched Databases}

- PubMed Advanced Search ( until July 2015)

- MEDLINE

- Cochrane Database of Systematic Reviews

2.2. Language

DOI: 10.9790/0853-15076129135 
There were no language restrictions.

\subsection{Hand Searching}

- Journal of American Science

- Australian Endodontic Journal

\subsection{Types of Studies}

Randomized controlled trials or clinical trials/studies or in-vivo studies evaluating post- treatment pain using different obturation methods and materials.

\subsection{Inclusion criteria}

Patients who are undergoing root canal therapy.

\subsection{Exclusion Criteria}

The following studies were excluded,

- $\quad$ Case reports/case series

- Animal studies

- In vitro studies

- Studies not meeting the inclusion criteria.

\subsection{Description of studies}

\section{Results}

1) The first search on obturation technique identified 340 publications out of which 329 were excluded after reviewing the title or abstract. Full articles were obtained for 10 studies, 9 of these publications were excluded after reading the full text article. So a total of 1 article fulfilled the inclusion criteria. 1 hand searched article which fulfilled the inclusion criteria. Therefore, a total of 2 publications fulfilled all criteria for inclusion (chart 1A).

2) The second search on obturation materials identified 172 publications out of which 170 were excluded after reviewing the title or abstract. Full articles were obtained for 3 studies, 1 of these publication was excluded after reading the full text article. Therefore, a total of 2 publications fulfilled all criteria for inclusion (chart 1B).

\section{Discussion}

The first search on obturation technique identified 340 publications out of which 329 were excluded after reviewing the title or abstract. Full articles were obtained for 10 studies, 9 of these publications were excluded after reading the full text article. So a total of 1 article fulfilled the inclusion criteria. 1 hand searched which fulfilled the inclusion criteria. Therefore, a total of 2 publications fulfilled all criteria for inclusion.

The second search on obturation materials identified 172 publications out of which 170 were excluded after reviewing the title or abstract. Full articles were obtained for 3 studies, 1 of these publication was excluded after reading the full text article. Therefore, a total of 2 publications fulfilled all criteria for inclusion.

\subsection{Interpretation of results}

According to Sahito et al (1), sixty patients were randomly divided into two groups $(\mathrm{n}=30)$. Group A: Obtura II and Group B: System B (table 1). According to this study at 72 hours, $38.7 \%$ patients experienced significant pain in group A and $36.3 \%$ patients in group B. This study concluded that there was no significant difference between two groups (table 2).

According to Louis $\mathrm{O}$ et al (2), 204 patients were randomly divided into three equal groups. Group-A: Cold lateral compaction of gutta - percha $(n=80)$, Group-B: Thermafil technique $(n=61)$, Group-C: Backfill Thermafil obturation technique $(n=63)$ (table 1). According to this study at the 6 th hour the postoperative mean values for three groups are $0.4 \pm 0.4,1.4 \pm 0.7$ and $0.4 \pm 0.3$ respectively. Group B has significantly higher mean pain level compared to Group A and Group C and there is no significant difference between Group A and Group C (table 2).

According to Tayfun et al (3), the study was conducted on 212 patients. Iodoform paste was used in 53 cases, Oxpara used in 52 cases, Endomethasone paste was used in 57 cases while AH26 was used in 50 cases (table 1). Pain experienced by the patient was then evaluated at 3rd and 7th day after treatment. At 3rd day, the patients experienced $13.2 \%$ of spontaneous pain in group 1, $15.25 \%$ in group 2, $12.2 \%$ in group 3 and $14 \%$ in group 4. At 7 th day, the percentage of pain decreased to $2.5 \%$. This study showed that there was no statistical difference between the presence and type of postoperative pain and the type of sealer used (table 2) 
According to Julius Fox et al (4), the study was conducted on 291 patients. Silver cone was given as filling material in 103 cases, Gutta-percha used in 119 cases and Silver cones supplemented with gutta - percha cones were used in 25 cases (table 1). In first postoperative day (24h) only 5 in group 1(4\%), 12 in group $2(10 \%)$ and 2 in group $3(8 \%)$ reported moderate pain. The results showed that there was no statistical difference between the three groups (table 2).

\subsection{Defending the Results}

Out of the four clinical trials included in this systematic review, two studies compared the influence of obturation techniques on post-obturation pain and two studies compared obturation material on post-obturation pain.

Out of two studies, one study have concluded that there is no difference in post-obturation pain between obturation techniques used (1). Other study concluded that post-obturation pain was significantly associated with obturation technique used in root canal treatment (2).

And two studies have concluded that there is no correlation between incidence and type of pain experienced and type of root canal sealer used $(3,4)$.

One study (2) compared Cold lateral compaction, Thermafil and a mixed obturation technique using thermafil and a master gutta-percha cone and they have concluded that mean pain level was higher in the patients treated with the Thermafil technique. Higher pain levels associated to thermafil technique was due to extrusion of gutta-percha that frequently occurs when this technique is used. However, Yesiloy et al did not find correlation between sealer extrusion and post-obturation pain.

Another study compared four different root canal sealers, Iodoform paste, Oxpara root canal paste, Endomethasone paste and AH 26 was used and they have concluded that there was no statistical significance between the presence and type of postoperative pain and the type of sealer used. Fox et al found that the type of filling material used (gutta-percha or silver points) had no significant influence upon postoperative pain.

Overall, from this systematic review it can be concluded that there is no conclusion evidence between the incidence and type of pain experienced and the type of obturation technique and material used.

\subsection{Quality of Evidence}

Four trials were included in this review. Two trials are of level of evidence 3. Thus the level of evidence is low (table 3). Risk of bias of 4 studies (Sahito et al, 2014, Luis O et al, 2012, Tayfun et al, 1985, Julius Fox et al, 1970) had a high risk of bias (table 4).

\subsection{Report on Outliers Data}

No outlier data obtained.

\subsection{Inference}

From this systematic review it can be concluded that there is no conclusion evidence between the incidence and type of pain experienced and the type of obturation technique and material used.

However, the number of good quality randomized controlled clinical trials included in this review is very limited. This shows the lack of evidence supporting the findings. Hence, more high quality clinical trials are required to prove various obturation techniques and materials in reducing post - operative pain.

\section{Conclusion}

From this systematic review it can be concluded that there is no conclusion evidence between the incidence and type of pain experienced and the type of obturation technique and material used.

Hence, more properly designed high quality randomized clinical trials are needed to evaluate the obturation technique and materials in reducing post - treatment pain.

\section{References}

[1]. Najma Sahito, Abdul Qadir Dal, Azizullah Qureshi. A clinical study of the Post Operative Pain after Root Canal Obturation with Obtura-Ii \& System-B, Warm Gutta-Percha Techniques. J Am Sci 2014;10(10):11-14 (8)

[2]. Alonso-Ezpeleta LO, Gasco-Garcia C, Castellanos-Cosano L, Martín-González J, López-Frías FJ, Segura-Egea JJ. Postoperative pain after onevisit root-canal treatment on teeth with vital pulps: Comparison of three different obturation techniques. Med Oral Patol Oral Cir Bucal. 2012 Jul1;17 (4):e7217.

[3]. Tayfun Alacam. Incidence of postoperative pain following the use of different sealers in immediate root canal filling. $\mathrm{J}$ Endod 1970;11:135-137.

[4]. Fox J, Atkinson JS, Dinin AP, et al. Incidence of pain following one-visit endodontic treatment. Oral Surg 1970;30:123-30.

[5]. Harrison JW, Baumgartner JC, Svec TA. Incidence of pain associated with clinical factors during and after root canal therapy. Part 2. Postobturation pain. J Endod. 1983;9:434-8.

[6]. Siqueira JF Jr, Rôças IN, Favieri A, Machado AG, Gahyva SM, Oliveira JC, Abad EC. Incidence of postoperative pain after intracanal procedures based on an antimicrobial strategy. J Endod 2002 Jun; 28(6):457-60. 
[7]. Gondim E Jr, Setzer FC, Dos Carmo CB, Kim S. Postoperative pain after the application of two different irrigation devices in a prospective randomized clinical trial. J Endod. 2010;36:129595-301.

[8]. Pack JG, White SN. Pain prevalence and severity before, during, and after root canal treatment: a systematic review. J Endod. 2011;37:429-38.

[9]. Vanotti A, Osio M, Mailland E, Nascimbene C, Capiluppi E, Mariani C. Overview on pathophysiology and newer approaches to treatment of peripheral neuropathies. CNS Drugs. 2007;21:3-12.

[10]. Genet JM, Hart AA, Wesselink PR, Thoden van Velzen SK. Preoperative and operative factors associated with pain after the first endodontic visit. Int Endod J. 1987;20:53-64.

[11]. Wolfe F, Michaud K. The Hawthorne effect, sponsored trials, and the overestimation of treatment effectiveness. J Rheumatol. 2010;37:2216-20.

[12]. Torabinejad M, Kettering JD, McGraw JC, Cummings RR, Dwyer TG, Tobias TS. Factors associated with endodontic interappointment emergencies of teeth with necrotic pulps. J Endod. 1988;14:261-6.

Chart 1a: Search Flow Chart (Obturation Techniques)

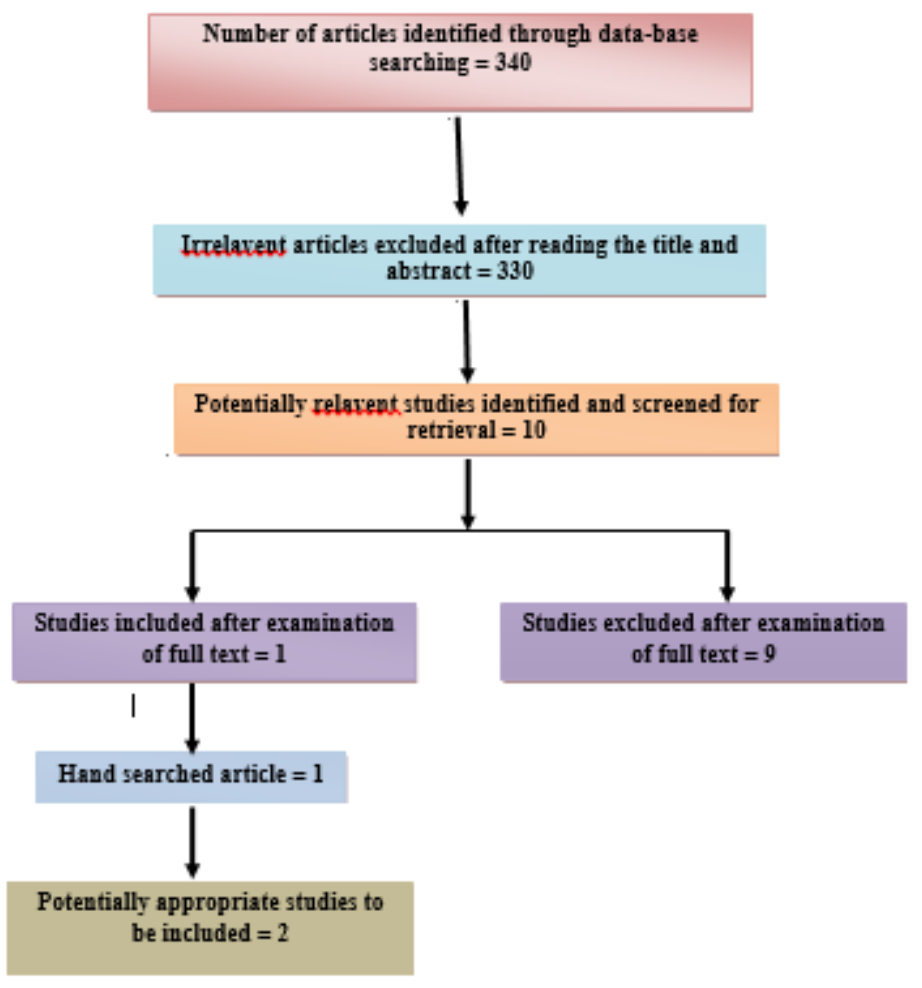


Chart 1b: Search Flow Chart (Obturation Materials)
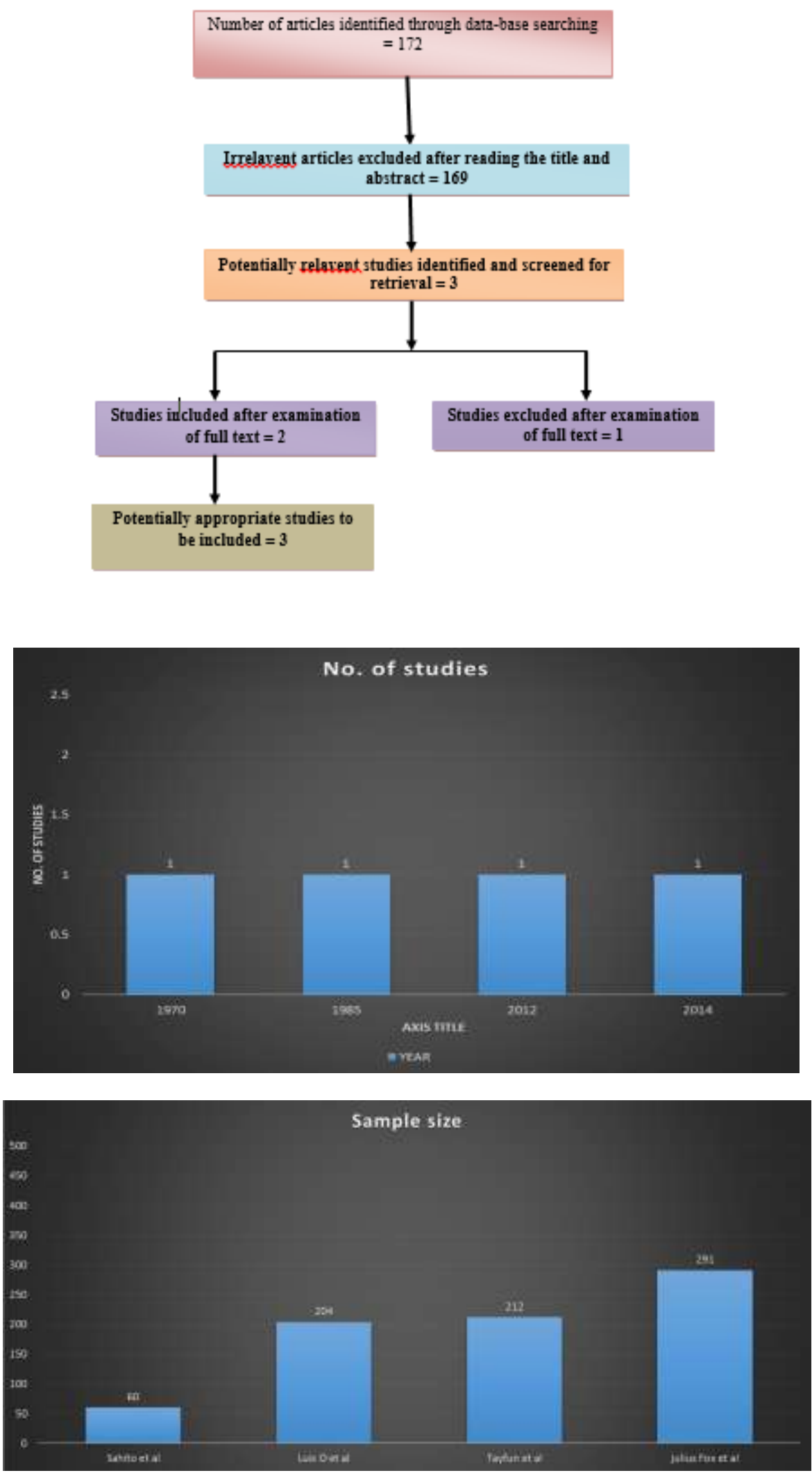
Table 1: General Information Of Selected Articles

\begin{tabular}{|c|c|c|c|c|c|c|c|c|c|}
\hline S. No & Author & Year & Country & $\begin{array}{l}\text { Study } \\
\text { Design }\end{array}$ & $\begin{array}{c}\text { Sample } \\
\text { Size }\end{array}$ & Age & Set-up & $\begin{array}{c}\text { Obturation } \\
\text { technique/ } \\
\text { Obturation } \\
\text { material }\end{array}$ & $\begin{array}{l}\text { Method of } \\
\text { evaluation }\end{array}$ \\
\hline 1. & $\begin{array}{l}\text { Sahito et } \\
\text { al }\end{array}$ & 2014 & Pakistan & $\begin{array}{l}\text { Cross } \\
\text { section } \\
\text { al } \\
\text { clinical } \\
\text { study }\end{array}$ & 60 & $\begin{array}{l}\text { Not } \\
\text { mentio } \\
\text { ned }\end{array}$ & University & $\begin{array}{l}\text { Group I: } \\
\text { Obtura II } \\
\text { technique } \\
\text { Group II: } \\
\text { System B } \\
\text { technique }\end{array}$ & $\begin{array}{l}\text { Visual analogue } \\
\text { scale }\end{array}$ \\
\hline 2. & $\begin{array}{l}\text { Luis O et } \\
\text { al }\end{array}$ & 2012 & Spain & $\begin{array}{l}\text { Rando } \\
\text { mized } \\
\text { clinical } \\
\text { trial }\end{array}$ & 204 & $\begin{array}{l}12- \\
77 y r s\end{array}$ & University & $\begin{array}{l}\text { Group 1: } \\
\text { Lateral } \\
\text { compaction } \\
\text { Group 2: } \\
\text { Thermafil } \\
\text { technique } \\
\text { Group 3: } \\
\text { Backfil } \\
\text { thermafil } \\
\text { technique }\end{array}$ & $\begin{array}{l}\text { Visual analogue } \\
\text { scale. }(10 \mathrm{~cm} \\
\text { scale) }\end{array}$ \\
\hline 3. & $\begin{array}{l}\text { Tayfun } \\
\text { Alacam et } \\
\text { al }\end{array}$ & 1985 & Turkey & $\begin{array}{l}\text { Clinica } \\
1 \text { study }\end{array}$ & 212 & $\begin{array}{l}\text { Not } \\
\text { mentio } \\
\text { ned }\end{array}$ & University & $\begin{array}{l}\text { Group 1: } \\
\text { Iodoform } \\
\text { paste } \\
\text { Group 2: } \\
\text { Oxpara } \\
\text { Group } \\
\text { 3:Endomethas } \\
\text { one } \\
\text { Group 4: AH } \\
\text { 26 }\end{array}$ & $\begin{array}{l}\text { Pain category: } \\
\text { 1)Spontaneous } \\
\text { pain } \\
\text { 2)Percussion } \\
\text { sensitivity } \\
\text { 3)Palpation pain }\end{array}$ \\
\hline 4. & $\begin{array}{l}\text { Julius Fox } \\
\text { et al }\end{array}$ & 1970 & USA & $\begin{array}{l}\text { Clinica } \\
1 \text { study }\end{array}$ & 291 & $\begin{array}{l}\text { Not } \\
\text { mentio } \\
\text { ned }\end{array}$ & University & $\begin{array}{l}\text { Group 1: } \\
\text { Silver cone } \\
\text { Group 2: } \\
\text { Gutta- percha } \\
\text { cone } \\
\text { Group 3: } \\
\text { Silver cone } \\
\text { supplemented } \\
\text { with gutta- } \\
\text { percha cones. }\end{array}$ & $\begin{array}{l}\text { Pain category: } \\
\text { 1) Spontaneous } \\
\text { pain } \\
\text { 2) Pericemental } \\
\text { pain }\end{array}$ \\
\hline
\end{tabular}

TABLE 2: RESULTS

\begin{tabular}{|c|c|c|c|c|c|c|c|c|}
\hline $\begin{array}{l}\text { S. } \\
\mathbf{N} \\
\mathbf{0}\end{array}$ & $\begin{array}{c}\text { Author } \\
\text { and } \\
\text { Year }\end{array}$ & $\begin{array}{c}\text { Obturation } \\
\text { material }\end{array}$ & $\begin{array}{l}\text { Obturation } \\
\text { technique }\end{array}$ & $\begin{array}{l}\text { Method of } \\
\text { Evaluation }\end{array}$ & $\begin{array}{c}\text { Statistical } \\
\text { test used }\end{array}$ & $\begin{array}{c}P \\
\text { value }\end{array}$ & $\begin{array}{c}\text { Mean } \\
\text { Values }\end{array}$ & Outcome \\
\hline 1. & $\begin{array}{l}\text { Sahito et } \\
\text { al, } 2014\end{array}$ & $\begin{array}{l}\text { Not } \\
\text { mentioned }\end{array}$ & $\begin{array}{l}\text { Group 1: } \\
\text { Obtura II } \\
\text { Group 2: } \\
\text { System B }\end{array}$ & $\begin{array}{l}\text { Visual } \\
\text { analogue } \\
\text { scale. }(10 \mathrm{~cm} \\
\text { scale) }\end{array}$ & $\begin{array}{l}\text { Fisher's } \\
\text { exact test }\end{array}$ & 0.04 & $\begin{array}{l}\text { At } 72 \text { hrs } \\
\text { Group 1: } \\
38.7 \% \\
\text { Group 2: } \\
36.3 \%\end{array}$ & $\begin{array}{l}\text { There is not much } \\
\text { statistical difference } \\
\text { in post obturation } \\
\text { pain within } 72 \text { hours } \\
\text { between Obtura II } \\
\text { and System B. }\end{array}$ \\
\hline 2. & $\begin{array}{l}\text { Luis O et } \\
\text { al, } \\
2012\end{array}$ & $\begin{array}{l}\text { AH plus } \\
\text { sealer }\end{array}$ & $\begin{array}{l}\text { Group 1: } \\
\text { Lateral } \\
\text { compaction } \\
\text { (n=80) } \\
\text { Group 2: } \\
\text { Thermafil } \\
\text { technique } \\
\text { (n=61) } \\
\text { Group 3: } \\
\text { Backfil } \\
\text { thermafil } \\
\text { technique } \\
\text { (n=63) }\end{array}$ & $\begin{array}{l}\text { Visual } \\
\text { analogue } \\
\text { scale. }(10 \mathrm{~cm} \\
\text { scale) }\end{array}$ & $\begin{array}{l}\text { Bivariate } \\
\text { and } \\
\text { multivariat } \\
\text { e analysis }\end{array}$ & $<0.05$ & $\begin{array}{l}\text { At } 6 \text { hrs } \\
\text { Group 1: } \\
70 \% \\
\text { Group 2: } \\
91 \% \\
\text { Group 3: } \\
100 \%\end{array}$ & $\begin{array}{l}\text { Group } 3 \text { showed } \\
\text { significantly higher } \\
\text { pain level than } \\
\text { group } 1 \text { and group } 2 .\end{array}$ \\
\hline 3. & $\begin{array}{l}\text { Tayfun } \\
\text { Alacam, } \\
1985\end{array}$ & $\begin{array}{l}\text { Group 1: } \\
\text { Iodoform } \\
\text { paste }\end{array}$ & $\begin{array}{l}\text { Lateral } \\
\text { condensation } \\
\text { technique }\end{array}$ & $\begin{array}{l}\text { Pain } \\
\text { category: } \\
\text { 1) }\end{array}$ & $\begin{array}{l}\text { Chi- } \\
\text { square test }\end{array}$ & $>0.05$ & At 3rd day & \\
\hline
\end{tabular}




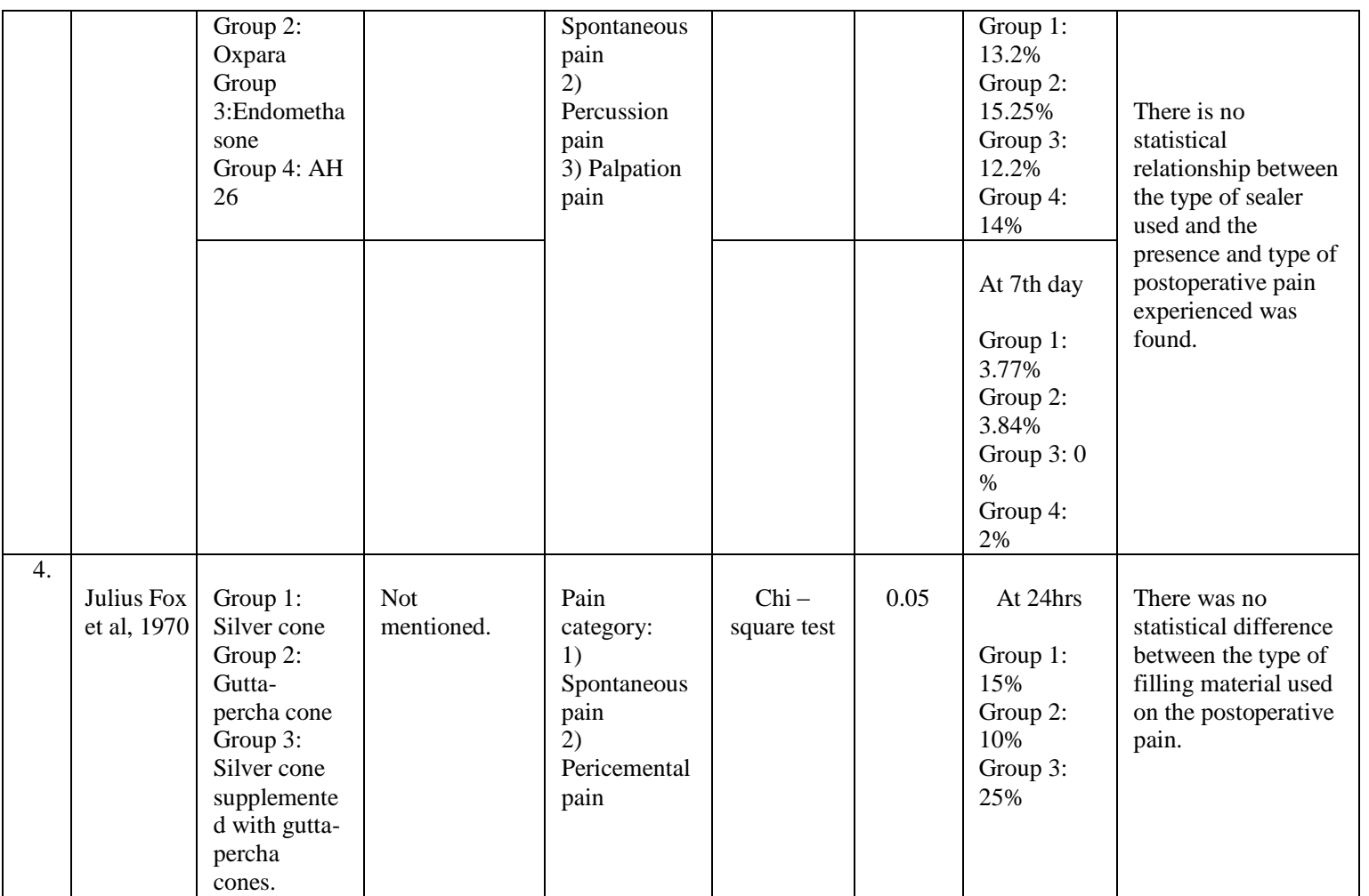

Table 3: Evidence Of Selected Articles

\begin{tabular}{|c|c|c|c|c|}
\hline S. No & Author & Year & Study Design & Level of Evidence \\
\hline 1. & Sahito et al & 2014 & Clinical trial & Level 3 \\
\hline 2. & Luis O et al & 2012 & Randomized clinical trial & Level 2 \\
\hline 3. & Tayfun Alacam & 1985 & Clinical study & Level 3 \\
\hline 4. & Julius Fox et al & 1970 & Clinical study & Level 3 \\
\hline
\end{tabular}

Table 4: Risk Of Bias - Major Criteria

\begin{tabular}{|c|c|c|c|c|c|c|}
\hline Serial No. & Study & Randomization & $\begin{array}{c}\text { Allocation } \\
\text { Concealed }\end{array}$ & $\begin{array}{c}\text { Assessor } \\
\text { Blinding }\end{array}$ & $\begin{array}{c}\text { Dropouts } \\
\text { Described }\end{array}$ & Risk of Bias \\
\hline 1. & Sahito et al, 2014 & Yes & No & No & No & High \\
\hline 2. & Luis O et al, 2012 & No & No & No & Yes & High \\
\hline 3. & Tayfun Alacam, 1985 & No & No & No & No & High \\
\hline 4. & Julius Fox et al, 1970 & No & No & No & No & High \\
\hline
\end{tabular}

